- уміння оцінювати комунікативну ситуацію швидко i на високому професійному рівні приймати рішення та планувати комунікативні дії.

Професійна мовна компетентність особистості $\epsilon$ показником сформованості системи професійних знань, комунікативних умінь і навичок, ціннісних орієнтацій, загальної гуманітарної культури, інтегральних показників культури мовлення, нсобхідних для якісної професійної діяльності.

Проблема формування мовної компетентності майбутніх педагогів не вичерпується результатом виконаної роботи. дослідження сприятиме розв'язанню проблеми наступності у формуванні мовленнєвих умінь і навичок між школою та вищим навчальним закладом в умовах відсутності україномовного середовища; подальшого вдосконалення різних видів мовленнєвої діяльності студентів під час вивчення українською мовою інших дисциплін.

\title{
Література
}

1. Байденко В. М. Концептуальная модель государственных образовательных компетентностей / В. М. Байденко. - М. : Просвещение, 2004. - 85 с. 2. Богуш А. М. Мовленнєва компетенція дошкільника як лінгводидактична проблема / А. М. Богуш, П. І. Білоусенко, І. Григоренко // Розвиток творчих здібностей дітей засобами мовлення: збірник наукових праць. - К., Запоріжжя, 1998. - С. 5-15. 3. Гез Н. И. Формирование коммуникативной компетенции как объекта зарубежных методических исследований / Н. И. Гез // Иностранные языки в школе. - 2001. № 2. - С. 17-24. 4. Эльконин Б. Д. Понятие компетентности с позиции развивающего обучения / Б. Д. Эльконин // Современные подходы к компетентностноориентированному образованию. - Красноярск, 2002. - 102 с. 5. Лозова В. І. Формування педагогічної компетентності викладачів вищих навчальних закладів/ В. І. Лозова // Педагогічна підготовка викладачів вищих навчальних закладів: Матеріали міжвуз. наук.-практ. конфер. - Харків : ОВС, 2002. - С. 38. б. Овчарук О. Компетентності як ключ до оновлення змісту освіти / О. Овчарук// Стратегія реформування освіти в Україні. - К., 2003. - 115 с.

УДК 37.037

Вікторія Яковлева

\section{ЯКІСНА ОСВІТА ЯК ПОКАЗНИК СТАНУ ГОТОВНОСТІ ПЕДАГОГІВ ДО ФОРМУВАННЯ ЖИТТЕВОЇ КОМПЕТЕНТНОСТІ УЧНІВ}

Яковлєва В. А. Якісна освіта як показник стану готовності педагогів до формування життєвої компетентності учнів

У статті визначені причини не сформованості життєвої компетентності учнів, проаналізовано рівень готовності випускників педагогічних ВН3 до вирішення професійних завдань (зокрема, формування життєвої компетентності учнів), теоретично обгрунтувано зміст поняття «готовність педагога щодо формування життєвої компетентності учнів».

Ключові слова: освіта, якість освіти, життєва компетентність, готовність до професійної діяльності.

Яковлева В. А. Качественное образование как показатель состояния готовности педагогов к формированию жизненной компетентности учащихся.

В статье определены причины не сформированности жизненной компетентности учащихся, проанализирован уровень готовности выпускников педагогических вузов к решению профессиональных задач (в частности, формирование жизненной 
компетентности учащихся), теоретически обосновано содержание понятия «готовность педагога к формированию жизненной компетентности учащихся».

Ключевые слова: образование, качество образования, жизненная компетентность, готовность к профессиональной деятельности.

Yakovleva V. A. Qualitative education as an indicator of teachers' readiness to form learners' life competency.

The article defines the reasons why learners' life competency has not been formed. The author analyzes the level of graduates' readiness to solve professional tasks (in particular, the formation of learners' life competency) and theoretically substantiates the meaning of the concept "teacher' readiness to form learners' life competency".

Key words: education, quality of education, life competency, readiness to professional activities.

Прийняття Національної доктрини розвитку освіти вимагає істотної модернізації педагогічного процесу в навчально-виховних закладах різних типів. Особливо актуальним нині є виявлення причин несформованості життєвої компетентності у молоді- важливого чинника соціалізації особистості та реалізації особистісно орієнтованого підходу до навчання i виховання, пошуку шляхів подолання суперечностей між особистістю і педагогічним впливом. Зростає потреба в нових концепціях структурування змісту педагогічних знань, методики й технології освітнього процесу, орієнтованого на особистість та забезпечення умов соціального становлення.

Розв'язання названих проблем багато в чому залежить від якості підготовки вчителя, рівня його професіоналізму i майстерності. Аналіз ситуації справ у педагогічній практиці та рівня готовності випускників педагогічних ВНЗ до розв'язання професійних завдань (зокрема формування життєвої компетентності учнів) свідчить про те, що якість їх підготовки ще не відповідає світовим стандартам. Причини цього слід убачати не тільки у змісті і характері викладання, але й у якості педагогічної освіти.

Освіта є одним із чинників соціалізації особистості. Ї̈ї соціальний аспект полягає в передаванні підростаючому поколінню знань, досвіду практичної діяльності, підготовці до свідомого вибору професії. Вона покликана формувати в молоді готовність до творчої, професійної діяльності і життя в суспільстві за законами моральності. Освіта працює на майбутнє, зумовлюючи якості кожної людини (його знання і вміння, світоглядні та поведінкові пріоритети), економічний, моральний, духовний потенціал суспільства. Соціальний характер освітнього процесу забезпечує якісну освіту, результат якого - фахівець з розвиненим інтелектом, сформованої культурою мови, готовий до самостійних і відповідальних дій і вчинків.

Системність і безперервність вивчення діяльності педагога вказують на необхідність багатоаспектного діагностування, залучаючи різні сторони педагогічної діяльності, професійно й соціально значущі якості особистості. Готовність учителів до формування життєвої компетентності учнів загальноосвітніх навчальних закладів складається із вивчення, порівняння, аналізу, інтерпретації досліджуваного матеріалу, i це - лише перший етап процедури передбачення. 3 ним органічно пов'язаний наступний - прогнозування розвитку подій і майбутніх наслідків у тих чи тих умовах. Педагогічний діагноз - надає вчителю оперативну i надійну інформацію про взаємозв'язок причин, які з них у певний момент небезпечні, а які - ефективні.

Теоретичний аналіз досліджень проблеми професійної готовності свідчить про те, що ця категорія має різноманітні психолого-педагогічні інтерпретації й 
розглядається як: стан підготовленості; специфічний стан; сукупність моральних, психологічних та професійних якостей $[2 ; 4 ; 5]$.

Теоретичний аналіз різноманітних напрямів дозволяє виокремити принципово значущі положення й констатувати певну єдність поглядів щодо проблеми професійної готовності:

- готовність як психічний стан не протиставляють готовності як якості особистості, оскільки вона в тому чи іншому випадку є психологічною передумовою ефективної діяльності;

- готовність як психологічний стан особистості - це внутрішня налаштованість на певну поведінку під час виконання навчальних та трудових завдань, настановлення на активні та цілеспрямовані дії під час навчання і в процесі роботи [2].

Готовність до професійної діяльності розглядається на функціональному, особистісно-діяльнісному, особистісному рівнях. На функціональному рівні готовність розглядається як тимчасова готовність та працездатність, передстартова активізація пізнавальних функцій). На особистісно-діяльнісному рівні готовність розглядається як цілісне виявлення усіх сторін особистості, що надає змогу виконувати свої функції.

Дослідники В. Аршавський, М. Дьяченко, Л. Кандибович, В. Ротенберг пов'язують готовність із психо-емоційним станом. Так, В. Аршавський, В. Ротенберг зазначають, що тривалі фрустрації та глибокі психічні хвилювання вбивають творчі елементи діяльності. Дослідники зазначають, що таких ситуацій можливо уникнути або звести їх до мінімуму, якщо людина буде озброєна прийомами саморегуляції, тим більше, що пошукова активність підвищує стійкість організму до впливу шкідливих чинників. Тому ауторегулятивні параметри особистості характеризують зміст психологічної готовності як один 3 найбільш значущих [1, с. 120].

На особистісному рівні генералізована особистісна готовність розглядається як виявлення індивідуально-особистісних якостей, що зумовлено характером майбутньої діяльності. Особистісний підхід до вивчення готовності щодо різних видів діяльності простежується в дослідженнях М. Дьяченка, Л. Кандибовича, К. Платонова та інших.

Mema cmammi: розглянути сутність поняття «Готовність до професійної діяльності» педагогів та проаналізувати вплив якості освіти на стан їх готовності до формування життєвої компетентності учнів середніх загальноосвітніх навчальних закладів.

На підставі аналізу наукових доробок робимо висновок, що готовність учителів до формування життєвої компетентності учнів загальноосвітніх навчальних закладів розуміється нами як стан учителя, що володіє системою знань 3 педагогічної діагностики, умінь i навичок, сформованих професійних здібностей, а також відповідних професійних якостей особистості педагога і може успішно здійснювати професійно-педагогічну діяльність.

У нашому дослідженні готовність педагогів до формування життєвої компетентності учнів загальноосвітніх навчальних закладів визначається як складне особистісне утворення, що забезпечує результативність професійної діяльності вчителя.

3 метою визначення рівня готовності педагогів до формування життєвої компетентності учнів, нами, перш за все було теоретично обгрунтувано зміст поняття «готовність педагога до формування життєвої компетентності учнів», яку ми розглядали в контексті більш широкої категорії «готовність особистості до професійної діяльності» (професійна готовність). Ця категорія є об’єктом постійної уваги психолого-педагогічної науки. У психології вона визначається як: стійка 
характеристика особистості, яка $є$ результатом підготовленості до діяльності;психічний стан; цілісний функціональний стан психіки $[4 ; 5 ; 6]$. Поняття «готовність» до виконання будь-якої діяльності, незважаючи на його широку розповсюдженість, має неоднозначну психолого-педагогічну інтерпретацію.

Одним із теоретичних підходів щодо вивчення готовності є трактування ії як підготовленості у безпосередньому зв'язку з формуванням та вдосконаленням психічних процесів, станів особистості, що $є$ необхідними для успішного виконання діяльності.

На думку В. Крутецького, готовність є синтез властивостей особистості, що означає іiї придатність до діяльності. До них дослідник відносить: активне позитивне ставлення до діяльності, схильність займатися нею, що перетворюється на пристрасне захоплення; низка характерологічних рис і стійкі інтелектуальні почуття; наявність під час діяльності сприятливих для іiї виконання психічних станів; певний запас знань, умінь і навичок у відповідній галузі; означені психологічні особливості в сенсорній та розумовій сферах, що відповідають вимогам цієї діяльності [5].

Дослідник О. Лішин розглядає готовність як налаштованість, актуалізацію та пристосування можливостей особистості для успішних дій у цей момент; внутрішню налаштованість особистості на певну поведінку у процесі виконання навчальних і трудових завдань, настанов на активні цілеспрямовані дії. «Готовність до того чи іншого виду діяльності - це цілеспрямоване вираження особистості, що включає іiі переконання, погляди, відносини, мотиви, почуття, вольові та інтелектуальні якості, знання, уміння, навички, настановлення, налаштованість на певну поведінку» [6, с. 4].

Ціннними вважаємо думки Я. Коломінського, який стверджує, що тільки в деяких випадках стан настановлень i стан готовності збігаються. Зазвичай, готовність - більш складне структурне утворення [4, с 18]. Дослідник стверджує, що на стан готовності впливають конкретні умови, у яких здійснюється діяльність. До числа зовнішніх та внутрішніх умов він відносить такі: зміст завдань, їх важкість, новизну, творчий характер; обставини діяльності, приклад поведінки оточуючих; особливості стимулювання дій та результатів; оцінку вірогідності його досягнення; самооцінку власної підготовленості; попередні нервово-психічні стани; стан здоров'я та фізичне самопочуття; особистий досвід, мобілізація сил на розв'язання завдань більшої важкості; уміння контролювати і регулювати рівень свого стану готовності; уміння самоналаштовуватися, створювати оптимальні внутрішні умови щодо майбутньої діяльності [4, с. 18-19].

Аналіз наукової літератури дозволяє стверджувати, що поняття «готовність до педагогічної діяльності» не має єдиного тлумачення. Однак, можна констатувати певну єдність поглядів сутності цього поняття:

- готовність - складне структурне утворення, у центрі якого перебуває усвідомлення педагогічної праці як головного сенсу життя;

- готовність до педагогічної діяльності передбачає сумлінне та відповідальне ставлення до педагогічної діяльності; прагнення виконувати іiі 3 позиції творчого підходу; сформованість стійких мотивів професійної діяльності; наявність професійних знань, умінь і навичок [2, с. 96 -98].

У контексті цього визначення готовність педагогів до формування життєвої компетентності учнів розуміється нами як частковий вияв готовності до самостійної педагогічної діяльності, як цілісне особистісне утворення.

Згідно 3 провідними ідеями теорії діяльності, виокремлення структури готовності педагогів до формування життєвої компетентності учнів, Л. Канішевська розглядає у єдності чотирьох взаємопов'язаних структурних компонентів: 
- ціннісно-мотиваційного, заснованого на стійкій спрямованості щодо організації процесу формування життєвої компетентності як актуального аспекту професійної діяльності, прагненні виконувати цю діяльність на високому рівні, спроможності забезпечити продуктивний розвиток вихованця школи-інтернату й закласти основи для власного професійного та особистісного зростання;

- когнітивного, який об'єднує сукупність знань педагога щодо його ролі у розвитку та саморозвитку особистості, яка формується в умовах позасімейного виховання, знання про сутність життєвої компетентності та специфіку їі формування у випускників загальноосвітніх закладів;

- діяльнісно-технологічного, який передбачає володіння формами і методами формування життєвої компетентності учнів;

- рефлексивного, який пов'язаний 3 аналізом процесу формування життєвої компетентності учнів; свого ставлення до даної сфери професійної діяльності, характеру та рівня їі виконання [3, с. 141-142].

Отже, подана структура готовності педагога до формування життєвої компетентності учнів загальноосвітніх навчальних закладів була взята нами за основу у ході проведення дослідно-експериментальної роботи.

Показниками готовності педагога до організації формування життєвої компетентності учнів загальноосвітніх закладів було визначено:

- емоційно-позитивну мотивацію щодо формування життєвої компетентності учнів; прагнення ефективно реалізувати іiі; учнів;

- знання про сутність життєвої компетентності та специфіку іï формування в

- володіння відповідними формами і методами виховання;

- рефлексивну позицію, яка пов'язана 3 адекватним оцінюванням себе як педагога, здатного формувати життєву компетентність у процесі його розвитку та саморозвитку тощо.

\section{Література}

1. Аршавский И. А. Физиологические механизмы и закономерности индивидуального развития / Илья Аркадьевич Аршавский. - М. : Наука, 1982. - 270 с. 2. Дьяченко М. И. Готовность к деятельности в напряженных ситуациях / М. И. Дьяченко, А. А. Деркач, Л. А. Кандыбович, В. А. Пономаренко. - Минск : Издво «Университетское», 1985. - 206 с. 3. Канішевська Л. В. Організаційно-методична підготовка педагогів до виховання соціальної зрілості старшокласників шкілінтернатів / Л. В. Канішевська // Теоретико-методичні проблеми виховання дітей та учнівської молоді : [зб. наук. праць]. - Ін-т проблем виховання АПН України, Київ : ТОВ «Імекс-ЛТД», 2008. - Вип. 11. $\quad 450$ с. - $\quad$ С. 134-143.

4. Коломинский Я. Л. Возрастная и педагогическая социальная психология в свете проблем воспитания / Я. Л. Коломинский // Прикладные проблемы социальной психологии. - $\quad$ М. : $\quad$ Наука, 1983. - С. 255-269. 5. Крутецкий В. А. Основы педагогической психологии. / Вадим Андреевич Крутецкий.- М.: Просвещение, 1972. - 255 с. 6. Лишин О. В. Педагогическая психология воспитания: учебное пособие [для школьных психологов]/ [под ред. Д.Й. Фельдштейна] / Олег Всеволодович Лишин. - М. : Институт практической психологии, 1997. - 256 с. 